\section{Identification of the Species Origin of Highly Processed Meat Products by Mitochondrial DNA Sequences}

\author{
Michael Unseld, Birgit \\ Beyermann, Petra Brandt, \\ and Rudolf Hiesel
}

Institut für Genbiologische Forschung, Ihnestrasse 63; 14195, Berlin, Germany
The increasing tendency toward processing agricultural products at or near the site of origin requires methods to identify the species of plant or animal used for the respective product. One of the major forms of conservation and processing of animal meat, particularly fish meat, relies on extensive cooking and subsequent canning procedures. The identification of the species from such preparations by conventional methods presents several difficulties. Classic methods used to identify species origins of meat usually depend on the stability of soluble proteins. Species-specific protein patterns can be obtained by gel electrophoresis. Immunological methods may be applied whenever intact proteins can be isolated. These methods, however, fail with highly processed samples such as cooked and canned meat. A protocol for species identification of processed meat by sequence analysis of the mitochondrially encoded gene for cytochrome $b$ has been published. ${ }^{(1)}$ This protocol was used successfully to amplify a 307-bp fragment of the cytochrome $b$ gene and to identify the species origin of various slightly processed tissue samples, including canned salmon meat. Although not detailed in this report, canned salmon is usually not cooked and autoclaved as is canned tuna meat but, rather, is smoked and canned in plant oil without extensive heat treatment. In our hands, however, this method failed to identify the species origin of canned tuna meat, as no amplification was observed. To expand the range of this application to identify the sources of processed meat, we have investigated the potential of the cytochrome $b$ gene for species identification of highly processed meat. Although more stable than the native configuration of proteins, DNA is also degraded by the action of radicals and heat. Progressive treatment and increased processing of meat products will thus increase the degradation of DNA and intensify the difficulties of recovering analyzable DNA. We now present an alternative procedure that allows the identification of tuna fish species even after extensive processing. In addition, we have introduced a cloning step before sequence analysis that enables us to analyze mixtures of more than one species. We chose the cytochrome $b$ gene as a molecular marker for several reasons. First, because of the maternal inheritance of mi- tochondria, normally only one allele exists in an individual and thus no sequence ambiguities are to be expected from the presence of more than one allele. Second, the high abundance of mitochondrial DNA in total cellular nucleic acid preparations allows more effective PCR amplifications in comparison to nuclear-encoded, single-copy genes. Third, in vertebrates the mutation rate of mitochondrial genes is $\sim 10$-fold higher compared to nuclear genes. Thus, point mutations accumulate quickly enough to allow (in most cases) the discrimination of even closely related species. Finally, cytochrome $b$ gene sequences have been, and are, extensively used in investigations of phylogenetic relationships within vertebrates. As a result, sequence data of many vertebrates are already available for comparisons. ${ }^{(2-7)}$ We have explored the potential of using mitochondrial cytochrome $b$ sequences for the identification of cooked and canned tuna fish species in commercial preparations. Here, we report the succesful identification of five different tuna species in a total of 30 commercially distributed cans.

\section{MATERIALS AND METHODS}

Canned tuna was purchased from local supermarkets or provided by the German customs authorities. Reference species were obtained as frozen samples by the German customs authorities.

\section{DNA Isolation}

Canned or frozen tissue ( $\sim 2$ grams) was washed with sterile water and cut into small pieces. The material was ground to a fine powder in liquid nitrogen, transferred to a centrifuge tube, and incubated at $60^{\circ} \mathrm{C}$ for $30 \mathrm{~min}$ in $5 \mathrm{ml}$ of a solution containing $4 \% \mathrm{~N}$-cetyl- $\mathrm{N}, \mathrm{N}, \mathrm{N}$ trimethyl-ammonium bromide (CTAB), $1.4 \mathrm{M} \mathrm{NaCl}, 20 \mathrm{~mm}$ EDTA, $100 \mathrm{~mm}$ Tris$\mathrm{HCl}(\mathrm{pH} \mathrm{8}$ ), and $100 \mathrm{~mm} \beta$-mercaptoethanol. After incubation the suspension was extracted once with chloroform/ isoamylalcohol (24:1), and nucleic acids were precipitated by adding two-thirds volume of isopropanol. Following centrifugation the pellet was washed once with $70 \%$ ethanol and dried under vacuum. Pellets were dissolved in an appropriate volume of TE $[10 \mathrm{~mm}$ Tris- $\mathrm{HCl}, 1$ mM EDTA (pH 8.0)] and stored frozen. 


\section{Amplification}

PCR reactions were performed in $100 \mu \mathrm{l}$ in $10 \mathrm{~mm}$ Tris- $\mathrm{HCl}(\mathrm{pH} 8.3)$ at $20^{\circ} \mathrm{C}, 1.5$ $\mathrm{mM} \mathrm{MgCl}_{2}$, and $50 \mathrm{~mm} \mathrm{KCl}$, with 100 pmoles of each primer, and 2.5 units of Taq polymerase (Boehringer Mannheim). The reaction mix was overlayered with $100 \mu \mathrm{l}$ of paraffin and 1 to $2 \mu \mathrm{g}$ of template DNA was added. The cycling conditions were $1 \mathrm{~min}$ at $94^{\circ} \mathrm{C}, 1 \mathrm{~min}$ at $50^{\circ} \mathrm{C}$, and $30 \mathrm{sec}$ at $72^{\circ} \mathrm{C}$ for 40 cycles in a Perkin-Elmer Cetus DNA thermal cycler. For amplification of the 402-bp fragment the elongation time was extended to $2 \mathrm{~min}$. PCR primers for the 402-bp fragment were $5^{\prime}$ primer, 5'CGAAGCTTGATATGAAAAACCATCGTTG-3'; and 3' primer, 5'-AAACTGCAGCCCCTCAGAATGATATTTGTCCTCA-3'. For the 59-bp fragment, the $5^{\prime}$ primer was replaced by 5'-GCTGGTACCTCTACAAAGAAACATGAAACA-3'. PCR products were purified by standard procedures $^{(8)}$ and ligated into pBluescript vectors using the HindIII or the KpnI sites introduced into the $5^{\prime}$ primers and the PstI site in the $3^{\prime}$ primer. Sequence analyses were carried out on a nonradioactive fluorescent on-line sequencer using the fluorescent sequencing kit from Pharmacia. Homology searches were done with the GCG package, version 7.

\section{RESULTS AND DISCUSSION}

\section{DNA Isolation}

The isolation protocol with CTAB adapted here was originally designed for green plant tissue. ${ }^{(9)}$ We have succesfully applied this method to a wide range of biological specimens such as green plants (fresh and dried material), dried mushrooms, coagulated blood, fresh and frozen animal tissue, as well as different processing forms of animal products (B. Beyermann and R. Hiesel, unpubl.). We have now extended the range of this application to canned fish meat and investigated the properties of the DNA isolated from canned tuna fish preparations. The DNA extracted from canned tuna meat was degraded to an average size of $\sim 100 \mathrm{bp}$ with only occasional faint traces of DNA molecules $\leqslant 2$ $\mathrm{kb}$ being visible on agarose gels. Such larger, less degraded DNAs are observed particularly in samples in which the tissue was canned in water rather than in plant oil. We have succesfully isolated DNA from 30 commercially available cans of different brands, including preparations in water, plant oil, and tomato sauces mixed with vegetables. All of these DNA preparations proved to be accessible to amplification by PCR with primer pairs specific for the mitochondrially encoded cytochrome $b$ gene.

\section{PCR Amplification}

A "universal" primer pair has been shown to amplify a 402-bp (464 bp with primers) segment of the cytochrome $b$ gene within a wide range of vertebrate species. ${ }^{(3,10)}$ These primers proved suitable with high-molecular-weight DNA isolated from freshly frozen tissue of five tuna and tuna-related species (Fig. 1). Damaged DNA isolated from canned samples offered as templates, however, could not be amplified between this primer pair. To rule out the possibility that some inhibitory substances copurified with the DNA, mixing experiments were performed by adding increasing amounts of the damaged DNA to PCR reactions set up with high-molecularweight DNA as templates. No inhibition was observed even when $\sim 10 \mu \mathrm{g}$ of damaged DNA was added (not shown). Thus, the lack of amplification products for the 402-bp segment is not attributable to inhibitory contaminants but, rather, is intrinsic to the DNA. These results confirm agarose gel analysis and suggest that no amplifiable molecules of the appropriate size are left in these highly degraded DNA preparations. We therefore reduced the size of the expected product to $59 \mathrm{bp}$ ( $123 \mathrm{bp}$ with primers) by designing a $5^{\prime}$ primer in a conserved region closer to the $3^{\prime}$ primer. PCR reactions with this new primer successfully yielded products of the expected sizes in all samples.

\section{Sequence Analyses}

Using the universal primer pair to amplify the 402-bp fragments of the cytochrome $b$ gene, we established the reference data for five tuna species with template DNA isolated from freshly frozen tissue. These sequences and additional data from seven other species investigated previously (Fig. 1) ${ }^{(6)}$, now allow the identification of 9 of 11 tuna species in canned material using the described procedures also from the 59-bp fragment selected for this highly damaged DNA. Of 11 species, 2 (Thunnus thynnus and Thunnus albacares) are indistinguishable because of complete sequence identity within the respective fragment. This observation reflects the close phylogenetic relationship within the genus Thunnus. ${ }^{(6)}$ If members of this genus are to be distinguished from each other, specialized PCR amplifying another part of the mitochondrial genome has to be used. More variable sequence regions such as the mitochondrial control region will yield the desired resolution on this level.

\section{Identification of Tuna Species}

By sequencing $>4$ independent clones from the PCR products obtained from each of a total of 30 commercial preparations, the origins of the fish meat could be assigned unambiguosly. $T$. thynnus or $T$. albacares, the two indistinguishible species, were identified five times. Four cans contained meat of $E u$ thynnus affinis. Katsuwonus pelamis was found seven times, and Sarda chiliensis was identified in two samples. Sequences obtained from four cans were identical to the reference sequence from Auxis thazard except for a single $\mathrm{T} \rightarrow \mathrm{C}$ transi-

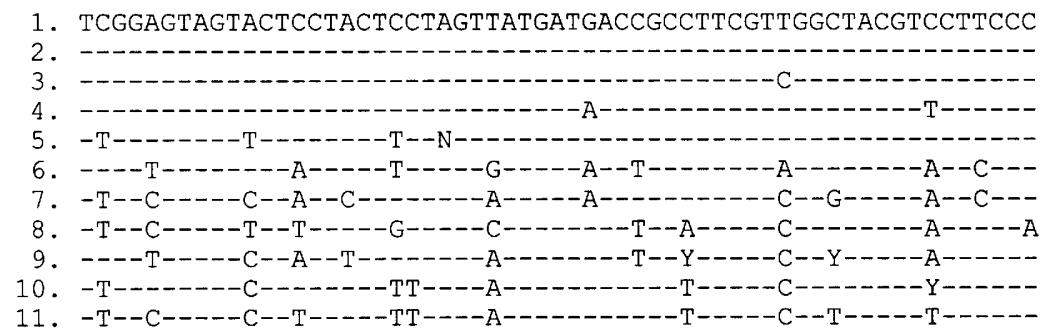

FIGURE 1 Nucleotide sequence alignment of the 59-bp cytochrome $b$ gene fragment from 11 tuna and tuna-related species. Asterisks $\left(^{*}\right)$ indicate sequences taken from the literature. ${ }^{(6)} 1$. Thunnus thynnus; 2 . Thunnus albacares; 3 . *Thunnus obesus; 4 . *Thunnus maccoyii; 5. *Thunnus alalunga; 6. Euthynnus affinis; 7. Euthynnus alleteratus; 8. *Auxis thazard; 9. *Katsuwonus pelamis; 10. *Sarda sarda; 11. Sarda chiliensis. 
tion in the second position of the sequence (Fig. 1). This may be attributable to intraspecific, possibly geographic variability, or to two previously unrecognized, closely related species within the same genus. Further reference data will be necessary to answer this question. In eight canned tuna meat samples, mixtures of two species were identified. One meat was identical to the reference sequence of $E$. affinis, whereas the other indicates $A$. thazard with the single $\mathrm{T} \rightarrow \mathrm{C}$ transition difference in seven of the eight samples. In a single can again $E$. affinis was identified in adition to $A$. thazard meat, whose cytochrome $b$ gene sequence in this instance was completely identical to the reference sequence.

\section{Future Aspects}

We have shown here the applicability of $\mathrm{PCR}$, in conjunction with cloning and subsequent sequence analysis, to species identification of highly processed biological material. Besides the identification of tuna species in canned samples, various other applications will be possible with the system described here. The specificity of the PCR primers used for the amplification of degraded tuna DNA is not restricted to fish sequences but can also amplify human DNA isolated from hair roots and pork DNA isolated from cooked sausages (R. Hiesel, unpubl.). The complete taxonomic range of vertebrate species that can be amplified with this primer pair is still open but includes species as diverse as fish and mammals. The rapidly growing data base of cytochrome $b$ gene sequences from vertebrate and nonvertebrate species will allow the design of alternative primers for species that may be not amplifiable with the primers used here. Species identification of highly processed preparations can now be done with confidence even if mixtures of more than one species are to be analyzed, thus resolving problems related to the increasing trend toward local and even on-site processing of meat. It is now feasible to determine the fish meat sources of cans processed on mother ships and to clarify problems regarding quotas, protected species, customs declarations, and import/export restrictions.

\section{ACKNOWLEDGMENTS}

We thank Dr. A. Brennicke for his help with the manuscript and Dr. Soldat for providing reference material.

\section{REFERENCES}

1. Barttlett, S.E. and W.S. Davidson. 1992. FINS (forensically informative nucleotide sequencing): A procedure for identifying the animal origin of biological specimens. BioTechniques 12: 408-411.

2. Kocher, T.D., W.K. Thomas, A. Meyer, S.V. Edwards, S. Pääbo, F.X. Villablanca, and A.C. Wilson. 1989. Dynamics of mitochondrial DNA evolution in animals: Amplification and sequencing with conserved primers. Proc. Natl. Acad. Sci. 86: 6196-6200.

3. Richman, A.D. and T. Price. 1992. Evolution of ecological differences in the old world leaf warblers. Nature 355: 817-821.

4. Bowen, B.W., W.S. Nelson, and J.C. Avise. 1993. A molecular phylogeny for marine turtles: Trait mapping, rate assessment, and conservation relevance. Proc. Natl. Acad. Sci. 90: 5574-5577.

5. Meyer, A., T.D. Kocher, P. Basasibwaki, and A.C. Wilson. 1990. Monophyletic origin of Lake Victoria cichlid fishes suggested by mitochondrial DNA sequences. Nature 347: 550-553.

6. Block, B.A., J.R. Finnerty, A.F.R. Steward, and J. Kidd. 1993. Evolution of endothermy in fish: Mapping physiological traits on a molecular phylogeny. Science 269: 210-214.

7. Ma, D., A. Zharkikh, D. Graur, J.L. VandeBerg, and W. Li. 1993. Structure and evolution of opossum, guinea pig, and porcupine cytochrome b genes. J. Mol. Evol. 36: $327-334$.

8. Sambrook, J., E.F. Fritsch, and T. Maniatis 1989. Molecular cloning: A laboratory manual, 2nd ed. Cold Spring Harbor Laboratory Press, Cold Spring Harbor, New York.

9. Doyle, J.J. and L. Doyle. 1990. Isolation of plant DNA from Fresh tissue. Focus 12: 13-15.

10. Pääbo, S., J.A. Gifford, and A.C. Wilson. 1988. Mitochondrial DNA sequences from a 7000-year old brain. Nucleic Acids Res. 16: 9775-9787.

Received September 6, 1994; accepted in revised form November 15, 1994. 


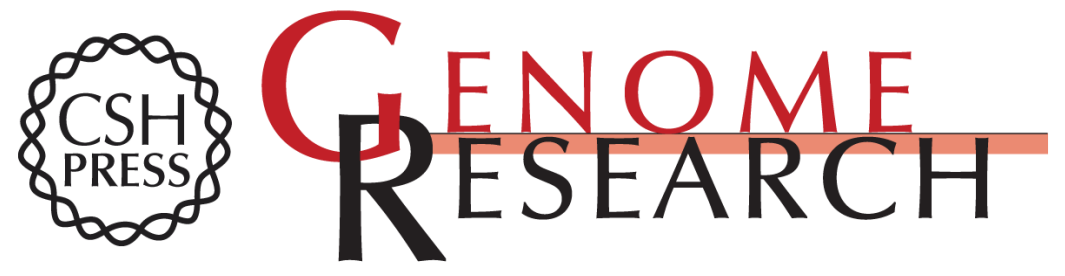

\section{Identification of the species origin of highly processed meat products by mitochondrial DNA sequences.}

M Unseld, B Beyermann, P Brandt, et al.

Genome Res. 1995 4: 241-243

References This article cites 9 articles, 2 of which can be accessed free at: http://genome.cshlp.org/content/4/4/241.full.html\#ref-list-1

License

Email Alerting

Receive free email alerts when new articles cite this article - sign up in the box at the Service top right corner of the article or click here.

\section{Affordable, Accurate Sequencing.}

To subscribe to Genome Research go to: https://genome.cshlp.org/subscriptions 